\title{
Original Article \\ Pengetahuan Wabah Covid-19 dan Aturan Kekarantinaan terhadap Kepatuhan dalam Upaya Pencegahan Covid-19
}

\author{
Teuku Muhammad Abdul Aziz $\mathrm{H}^{1}$, Yeni Koto ${ }^{2}$, Eka Rokhmiati ${ }^{3}$ \\ 1,2,3 Program Studi Ilmu Keperawatan Sekolah Tinggi Ilmu Kesehatan Indonesia Maju \\ Jln. Harapan No.50, Lenteng Agung - Jakarta Selatan 12610 \\ Email : aaziz123995@gmail.com ${ }^{1}$, kyoto.yeni16@gmail.com²
}

Editor: WK

Diterima: 11 September 2021

Direview: 23 September 2021

Publish: 16 November 2021

Available Article: (doi)

Hak Cipta:

(C)2021 Artikel ini memiliki akses terbuka dan dapat didistribusikan berdasarkan ketentuan Lisensi Atribusi Creative Commons, yang memungkinkan penggunaan, distribusi, dan reproduksi yang tidak dibatasi dalam media apa pun, asalkan nama penulis dan sumber asli disertakan. Karya ini dilisensikan di bawah Lisensi Creative Commons Attribution-Share Alike 4.0 Internasional.

\begin{abstract}
Abstrak
Pendahuluan: Pengetahuan yang rendah tentang wabah Covid19 dan kontak yang erat dengan pasien terinfeksi Covid-19 akan mempermudah proses penularan Covid-19 antara manusia. Sehingga himbauan kepada masyarakat untuk menjaga jarak fisik, melakukan berbagai kegiatan dari rumah, seperti bekerja, beribadah, dan belajar utuk mencegah menyebarnya Covid-19 di masyarakat.
\end{abstract}

Tujuan: Penelitian ini bertujuan untuk mengetahui hubungan antara pengetahuan tentang wabah Covid-19 dan aturan kekarantinaan terhadap kepatuhan dalam upaya pencegahan Covid-19 di Desa Dramaga Bogor.

Metode: Penelitian ini menggunakan pendekatan cross sectional dengan teknik pengambilan sampel secara accidental sampling. Jumlah responden 114 warga Desa Dramaga. Instrumen penelitian menggunakan kuesioner. Uji statistik menggunakan uji Chi square dengan tingkat kemaknaan $\alpha 0,05$.

Hasil: Hasil uji chi square menunjukkan ada hubungan pengetahuan wabah Covid-19 terhadap kepatuhan dalam upaya pencegahan Covid-19 di Desa Dramaga Bogor dengan Pvalue $0,000<0,05$.

Kesimpulan: Terdapat hubungan antara pengetahuan tentang wabah Covid-19 terhadap kepatuhan dalam upaya pencegahan Covid-19 di Desa Dramaga Bogor.

Kata kunci: covid-19, karantina, kepatuhan, pengetahuan. 


\section{Pendahuluan}

Dunia internasional saat ini sedang marak-maraknya pandemi Covid-19 (Coronavirus Disease 2019). ${ }^{1}$ Kasus virus corona muncul dan menyerang manusia pertama kali di Provinsi Wuhan, China. Awal kemunculannya diduga merupakan penyakit pneumonia, dengan gejala serupa sakit flu pada umumnya. Gejala tersebut diantaranya batuk, demam, letih, sesak napas, dan tidak nafsu makan. Namun berbeda dengan influenza, virus corona dapat berkembang dengan cepat hingga mengakibatkan infeksi lebih parah dan gagal organ serta kematian. Kondisi darurat ini terutama terjadi pada pasien yang memiliki masalah kesehatan sebelumnya atau memiliki penyakit bawaan. ${ }^{1}$

Proses penularan Covid-19 kepada manusia harus diperantarai oleh reservoir kunci yaitu alphacoronavirus dan betacoronavirus yang memiliki kemampuan menginfeksi manusia. Kontak yang erat dengan pasien terinfeksi Covid-19 akan mempermudah proses penularan Covid-19 antara manusia. ${ }^{1}$ Proses penularan Covid-19 disebabkan oleh pengeluaran droplet yang mengandung virus Sars-CoV-2 ke udara oleh pasien terinfeksi pada saat batuk ataupun bersin. Droplet di udara selanjutnya dapat terhirup oleh manusia lain di dekatnya yang tidak terinfeksi Covid-19 melalui hidung atau pun mulut dan masuk menembus paru-paru dan proses infeksi pada manusia berlanjut. ${ }^{2}$

Menanggapi pandemi Covid-19, disamping tahapan kesehatan masyarakat yang lebih rutin, banyak negara telah menerapkan "lockdown" yaitu menutup perbatasan, membatasi perjalanan internasional, dan menempatkan batasan berat pada pergerakan individu dan pertemuan kelompok. Walaupun lockdown mungkin merupakan alat penting untuk membatasi penularan, namun lockdown berpotensi menimbulkan biaya besar berkaitan dengan dampak ekonomi, konsekuensi kesehatan mental, dan peningkatan morbiditas dan mortalitas dari penyakit non Covid-19. ${ }^{2}$ Karantina, lockdown atau aturan physical distancing mencerminkan perubahan yang cepat dan substansial dalam kehidupan sehari-hari. Lelucon dan video lucu dapat membantu orang untuk menerima perubahan dalam hidup mereka. Perubahan tersebut menghasilkan banyak sumber ketidakpastian dan stres, yang sebagian dapat meringankan, setidaknya dalam jangka pendek. ${ }^{3}$ Demi upaya pencegahan tersebut, pemerintah Indonesia memberikan himbauan kepada masyarakat untuk menjaga jarak fisik (physical distancing), melakukan berbagai kegiatan dari rumah (social ditancing), seperti bekerja, hingga beribadah, dan juga melakukan karantina serta belajar mengetahui bagaimana cara virus Covid-19 menyebar pada setiap masyarakat, maka dari itu pentingnya pengetahuan akan wabah Covid19 untuk mengurangi laju penyebarannya. ${ }^{3}$

Penelitian ini sejalan dengan hasil penelitian yang dilakukan oleh Devi Pramita, tentang hubungan antara pengetahuan masyarakat dengan kepatuhan penggunaan masker sebagai upaya pencegahan penyakit Covid-19 di Ngronggah dimana hasil penelitian ini dari 62 responden berdasarkan hasil uji Chi-Square signifikansi $\mathrm{p}$ anatara variabel bebas yaitu pengetahuan masyarakat dengan variabel terikat kepatuhan penggunaan masker sebesar 0,004 $(\mathrm{p}<0,05)$ maka Ho ditolak dan dinyatakan ada hubungan ${ }^{4}$

Pengetahuan tentang penyakit Covid-19 merupakan hal yang sangat penting agar tidak menimbulkan peningkatan jumlah kasus penyakit Covid-19. Pengetahuan pasien Covid-19 19 dapat diartikan sebagai hasil tahu dari pasien mengenai penyakitnya, memahami penyakitnya, cara pencegahan, pengobatan dan komplikasinya. Pengetahuan penderita tentang pencegahan Covid-19 dengan kepatuhan penggunaan masker memiliki peranan penting dalam 
mengantisipasi kejadian berulang. Namun pada kenyataannya tingkat pengetahuan masyarakat Indonesia terkait Covid-19 dan aturan kekarantinaan masih rendah. ${ }^{5}$

Data terbaru penyebaran akan wabah Covid-19 bulan Oktober 2020 melalui situs dimana angka penyebaran Covid-19 didunia mencapai 38.727.888 kasus, sedangkan untuk Indonesia angka penyebaran Covid-19terbaru mencapai 344.749 kasus penambahan, pada penelitian ini daerah yang dijadikan lokasi penelitian akan penyebaran Covid-19 adalah Desa Dramaga RT 1 RW 5, dimana pada Desa Dramaga ini pada bulan Juni mengalami kenaikan kasus positif Covid-19 sebanyak 4 orang yang menjadi Desa Dramaga menjadi cluster zona merah di Kabupaten Bogor. ${ }^{6}$

Peneliti melakukan survei di lokasi penelitian, meskipun klaster dan penderita Covid19 di Desa Dramaga bertambah sebanyak 20 orang, masyarakat sekitar masih belum mematuhi protokol atau anjuran 3M (memakai masker, mencuci tangan, dan menjaga jarak) yang diberikan oleh pemerintah. Petugas keamanan dan Dinas Perhubungan Kabupaten Bogor melakukan operasi yustisi untuk menegakkan peraturan wajib memakai masker. Tetapi, masih banyak ditemukan warga yang tidak memakai masker, sehingga masih banyak yang terjaring operasi dan mendapatkan denda maupun saksi sosial. Sebelumnya, Muspika (Musyawarah Pimpinan Kecamatan) melakukan operasi yustisi pada tanggal 25 September 2020 di Pasar Dramaga dan tiga lokasi perdagangan di jalan raya Dramaga. Pada operasi ini, petugas keamanan lebih memusatkan pada penggunaan masker dan sayangnya, hanya dalam waktu operasi yang sebentar, ada 26 pelanggar yang diberikan sanksi oleh pihak yang berwajib.

Tujuan penelitian ini adalah untuk mengetahui hubungan antara pengetahuan tentang wabah Covid-19 dan aturan kekarantinaan terhadap kepatuhan dalam upaya pencegahan Covid-19 di Desa Dramaga Bogor.

\section{Metode}

Desain penelitian yang digunakan dalam penelitian ini adalah observasional analitik. Jenis penelitian kuantitatif menggunakan rancangan penelitian Cross Sectional yaitu menekankan waktu pengukuran atau observasi data variabel independen dan dependen hanya satu kali pada satu saat. ${ }^{7}$ Populasi dalam penelitian ini adalah semua warga Desa Dramaga Bogor dan sampel terpilih sebanyak 114 respoden dengan menggunakan teknik accidental sampling. Sebelum melakukan penelitian kepada responden terpilih, peneliti terlebih dahulu melakukan uji etical clearance yang sudah disahkan oleh Sekolah Tinggi Ilmu Kesehatan Indonesia Maju Jakarta pada tanggal 13 Maret 2021 dengan nomer uji etik: 192/Sket/KaDept/RE/STIKIM/III/2021.

Penelitian ini dilaksanakan di Desa Dramaga Bogor. Pengambilan data penelitian dilaksanakan pada bulan Ferbuari- Maret Tahun 2021. Analisa univariat digunakan untuk mendeskripsikan variabel yang diteliti dengan cara membuat tabel distribusi frekuensi, dan data disajikan dalam bentuk persentase. Uji Statistik yang akan digunakan dalam analisa bivariat dalam penelitian ini adalah uji Chi square. ${ }^{9}$

\section{Hasil}

Hasil penelitian univariat yaitu karakteristik responden seperti usia, jenis kelamin, pendidikan warga Desa Dramaga Bogor. 
Tabel 1. Distribusi Frekuensi Karakteristik Responden $(\mathrm{n}=114)$

\begin{tabular}{lcc}
\hline Karakteristik & Jumlah (n) & Presentasi (\%) \\
\hline Usia & 74 & 65 \\
$25-45$ Tahun & 40 & 35 \\
46-60 Tahun & & \\
Jenis Kelamin & 83 & 73 \\
Laki-laki & 31 & 27 \\
Perempuan & & \\
Pendidikan & 18 & 16 \\
SD & 17 & 15 \\
SLTP & 64 & 56 \\
SLTA & 15 & 13 \\
Perguruan Tinggi & & \\
\hline
\end{tabular}

Berdasarkan tabel 1, menunjukkan bahwa responden pada penelitian ini responden yang sebagian besar umur pasien 25 - 45 tahun yaitu sebanyak 74 orang $(64,9 \%)$. Sedangkan yang berusia 46-60 tahun yaitu 40 orang $(35,1 \%)$. Responden dengan jenis kelamin pasien terbanyak yaitu laki-laki sebanyak 83 orang $(72,8 \%)$, sedangkan yang perempuan hanya 31 orang $(27,2 \%)$.

Responden dengan tingkat pendidikan terbanyak yaitu SMA sebanyak 64 orang $(56,1 \%)$, SMP sebanyak 17 orang (14,9\%), PT/Akademik yaitu 15 orang (13,2\%), SD yaitu 11 orang $(9,6 \%)$ sedangkan yang tidak sekolah hanya 7 orang $(6,1 \%)$.

Tabel 2. Distribusi Frekuensi Pengetahuan Dan Kepatuhan Warga Desa Dramaga Bogor $(\mathrm{n}=114)$

\begin{tabular}{lcc}
\hline Variabel & $\begin{array}{c}\text { Jumlah } \\
(\mathbf{n})\end{array}$ & $\begin{array}{c}\text { Presentasi } \\
(\boldsymbol{\%})\end{array}$ \\
\hline Pengetahuan Covid-19 & 85 & 75 \\
Kurang & 29 & 25 \\
Baik & & \\
Kepatuhan & 80 & 70 \\
Patuh & 34 & 30 \\
Tidak patuh & & \\
\hline
\end{tabular}

Berdasarkan tabel 2 menunjukkan bahwa pada responden dengan pengetahuan tentang wabah Covid-19 dan aturan karantina yang baik sebanyak 85 orang $(74,6 \%)$ dan pengetahuan tentang wabah Covid-19 dan aturan karantina yang kurang baik yaitu 29 orang $(25,4 \%)$. Sedangkan masyarakat yang patuh terhadap anjuran pemerintah dalam pencegahan Covid-19 sebanyak 80 orang $(70,2 \%)$ yang tidak patuh terhadap anjuran pemerintah dalam pencegahan Covid-19 yaitu 34 orang $(29,8 \%)$.

Analisis bivariat dalam penelitian ini digunakan untuk mengetahui hubungan antara pengetahuan tentang wabah Covid-19 dan aturan kekarantinaan terhadap kepatuhan dalam upaya pencegahan Covid-19 di Desa Dramaga Bogor. Hasil analisis mengenai hubungan antara pengetahuan tentang wabah Covid-19 dan aturan kekarantinaan terhadap kepatuhan dalam upaya pencegahan Covid-19 yang dilaksanakan di Desa Dramaga Bogor, dapat disajikan pada tabel 3.

Tabel 3. Hubungan Pengetahuan Wabah Covid-19 terhadap Kepatuhan dalam Upaya Pencegahan Covid-19 di Desa Dramaga Bogor Tahun 2020

\begin{tabular}{|c|c|c|c|c|c|c|}
\hline \multirow{3}{*}{$\begin{array}{l}\text { Pengetahuan } \\
\text { Covid-19dan } \\
\text { Karantina }\end{array}$} & \multirow{3}{*}{$\begin{array}{l}\text { Wabah } \\
\text { aturan }\end{array}$} & \multicolumn{2}{|l|}{ Kepatuhan } & \multirow[b]{2}{*}{ Total } & \multirow{3}{*}{$\begin{array}{l}P \\
\text { Value }\end{array}$} & \multirow{3}{*}{$\begin{array}{l}\text { Odds Ratio } \\
95 \%\end{array}$} \\
\hline & & Patuh & Tidak Patuh & & & \\
\hline & & $\%$ & $\mathrm{n}$ & $\%$ & & \\
\hline
\end{tabular}




\begin{tabular}{|c|c|c|c|c|c|c|c|c|}
\hline & & & & & P-IS & $\begin{array}{l}\text { /ol. } 0 \\
2798\end{array}$ & $\begin{array}{l}\text { No. } 02 \\
2033, \mathrm{E} \\
\text { OI } 10.5\end{array}$ & $\begin{array}{l}\text { ember } \\
\text { 2798- } \\
\text { Dajjhs.v }\end{array}$ \\
\hline Baik & 73 & 64 & 12 & 10,5 & 85 & 74,6 & \multirow{3}{*}{0,000} & \multirow{3}{*}{19.119} \\
\hline Kurang Baik & 7 & 6,1 & 22 & 19,3 & 29 & 25,4 & & \\
\hline Total & 80 & 70,2 & 34 & 29,8 & 114 & 100 & & \\
\hline
\end{tabular}

Hasil penelitian dari 114 responden sebagian besar memiliki pengetahuan tentang wabah Covid-19 dan aturan karantina yang baik sebanyak 85 orang $(74,6 \%)$ memiliki hubungan kuat dengan kepatuhan masyarakat dalam upaya pencegahan Covid-19 yang patuh sebanyak 73 orang (64\%) yang tidak patuh dalam upaya pencegahan Covid-19 sebanyak 12 orang $(10,5 \%)$. Namun pengetahuan tentang wabah Covid-19 yang kurang baik sebanyak 29 orang $(25,4 \%)$, masyarakat yang patuh yaitu 7 orang $(6,1 \%)$ sedangkan masyarakat yang kurang patuh yaitu 22 orang $(19,3 \%)$.

Berdasarkan hasil uji statistic Chi-Square dengan nilai Pearson chi-quare dengan nilai value 39.387 menggunakan SPSS 20 dengan tingkat kemaknaan 95\%, menunjukkan bahwa nilai probabilitas $0,000(\mathrm{p}<0,05)$, artinya Ho di tolak dan Ha diterima. Maka dapat disimpulkan bahwa ada yang signifikan dari hasil analisis mengenai hubungan antara pengetahuan tentang wabah Covid-19 terhadap kepatuhan dalam upaya pencegahan Covid-19 di Desa Dramaga Bogor. Hasil analisa juga didapatkan data nilai Ordo Ratio sebesar 19.119 artinya yang memiliki pengetahuan tentang wabah kurang baik tentang Covid-19 dengan beresiko 22 kali kepatuhan masyarakat dalam upaya pencegahan Covid-19 yang kurang patuh dibandingkan dengan yang memiliki pengetahuan yang baik.

\section{Pembahasan}

\section{Gambaran Karakteristik Umur, Jenis Kelamin dan, Pendidikan}

Hasil analisis univariat karakteristik responden pada penelitian ini yang sebagian besar umur 25 - 45 tahun yaitu sebanyak 74 orang (64,9\%). Sedangkan yang berusia 46-60 tahun yaitu 40 orang $(35,1 \%)$. Faktor usia dimana usia mempengaruhi daya tangkap dan pola pikir seseorang, semakin bertambah usia maka akan semakin berkembang pula daya tangkap dan pola pikirnya sehingga pengetahuan yang diperoleh semakin baik, usia rata rata responden yang mengisi kuisioner ini berusia 27-28 tahun, dengan usia responden termuda yaitu 25 tahun dan yang paling tua berusia 60 tahun. ${ }^{10}$ Menurut asumsi peneliti bahwa umur bertambahnya seseorang akan semakin terbentuk sikap untuk lebih memperhatikan kesehatan diri sendiri sehingga hal tersebut akan meningkatkan pemahaman seseorang sehingga penyebaran Covid19 dapat dicegah sedini mungkin.

Hasil analisis univariat pada penelitian ini responden dengan jenis kelamin terbanyak yaitu laki-laki sebanyak 83 orang $(72,8 \%)$, sedangkan yang perempuan hanya 31 orang $(27,2 \%)$. Jenis kelamin merupakan suatu perbedaan keadaan fisiologis bawaan lahir yang dapat ditandai dengan jenis kelamin laki-laki dan perempuan. Seseorang yang berjenis kelamin perempuan cenderung mempunyai kecemasan tinggi dibandingkan laki-laki hal ini karena perempuan mempunyai perasaan lebih sensitif dibanding laki-laki dan tidak menutup kemungkinan terjadi pada laki-laki. ${ }^{10}$ Menurut asumsi peneliti bahwa karakteristik responden jenis kelamin teridentifikasi bahwa pada laki-laki lebih banyak mendapatkan informasi tentang Covid-19 . Dimana mereka sering menonton berita, membaca Koran dan browsing. Pada lakilaki maupun perempuan yang merasa mendapat pemahaman tentang Covid-19 dan perhatian dari anggota keluarga sesuai yang diinginkan akan memiliki persepsi bahwa dukungan dari keluarga untuk saling menjaga kesehatan. 
Hasil analisis univariat karakteristik responden pada penelitian ini yang sebagian besar memiliki tingkat pendidikan terbanyak yaitu SMA sebanyak 64 orang $(56,1 \%)$, SMP sebanyak 17 orang (14,9\%), PT/Akademik yaitu 15 orang $(13,2 \%)$, SD yaitu 11 orang $(9,6 \%)$ sedangkan yang tidak sekolah hanya 7 orang $(6,1 \%)$. Tingkat pendidikan seseorang yang tinggi akan semkin mudah untuk mendapatkan akses informasi tentang suatu permasalahan. ${ }^{7}$ Menurut Chekwueh dkk Pendidikan berkelanjutan diperlukan untuk meningkatkan pengetahuan dan mengubah sikap negative serta meningkatkan praktik pencegahan dan pengobatan. Pengetahuan dipengaruhi oleh beberapa faktor yaitu faktor pendidikan yang merupakan suatu usaha untuk mengembangkan kepribadian dan kemampuan didalam dan diluar sekolah baik formal maupun non formal dan berlangsung seumur hidup disebutkan bahwa makin tinggi pendidikan seseorang. ${ }^{7}$

Menurut asumsi peneliti bahwa semakin mudah orang tersebut menerima informasi, faktor infomasi atau media masa dengan berkembangnya teknologi akan menyediakan bermacam-maca media massa yang dapat mempengaruhi pengetahuan masyarakat tentang informasi terbaru, sehingga saran komunikasi seperti televisi, radio, surat kabar, majalah dan lain lain mempunyai pengaruh besar terhadap penyampaian opini dan kepercayaan sesorang.

\section{Gambaran Pengetahuan}

Pengetahuan tentang wabah Covid-19 dan aturan karantina yang baik sebanyak 85 orang $(74,6 \%)$ dan pengetahuan tentang wabah Covid-19 dan aturan karantina yang kurang baik yaitu 29 orang $(25,4 \%)$. Menurut Teori Wawan dan Dewi mendeskripsikan bahwa pengetahuan merupakan hasil "tahu" dan ini terjadi setelah orang mengadakan penginderaan terhadap suatu objek tertentu. Pengetahuan tentang berbagai cara dalam mencapai pemeliharaan kesehatan, cara menghindari penyakit, maka akan meningkatkan pengetahuan masyarakat. ${ }^{8}$

Hasil penelitian ini sejalan dengan penelitan yang dilakukan oleh Mona, Pengetahuan pasien Covid-19 dapat diartikan sebagai hasil tahu dari pasien mengenai penyakitnya, memahami penyakitnya, cara pencegahan, pengobatan dan komplikasinya. ${ }^{1}$ Hingga saat ini, Covid-19 telah menginfeksi lebih dari 1,5 juta (satu setengah juta) manusia di seluruh penjuru dunia, termasuk di Indonesia. Beberapa negara memberlakukan lockdown demi menekan angka penyebaran. Ada juga negara yang mengandalkan rapid test secara massif tanpa memberlakukan lockdown. Tetapi satu hal yang menjadi kesamaan di berbagai negara untuk menekan angka penyebaran, yaitu mengurangi aktivitas sosial dan perkumpulan massal. Secara umum tanggung jawab pemerintah pusat dan pemerintah daerah adalah melindungi kesehatan masyarakat yang berpotensi menimbulkan kedaruratan kesehatan masyarakat. Pemerintah pusat dan pemerintah daerah juga bertanggung jawab terhadap sumber daya yang diperlukan dalam pemyelenggaraan kekarantinaan kesehatan. Jika selama karantina wilayah, kebutuhan dasar orang dan makanan hewan ternak yang berada di wilayah karantina menjadi tanggung jawab Pemerintah Pusat. Maka dalam aturan PSBB tidak termuat hal tersebut. Bahkan tanggung jawab pemerintah pusat selama PSBB tidak diatur dalam undang-undang kekarantinaan kesehatan.

Menurut analisis peneliti bahwa Menurut Analisis peneliti bahwa masyarakat harus mengenal, mempelajari dan memahami segala aspek dari penyakit Covid-19 termasuk manifestasi klinis, penyebab, pencetus, pencegahan dan penatalaksanaan. Pengetahuan memiliki kaitan yang erat dengan keputusan yang akan diambilnya, karena dengan 
pengetahuan seseorang memiliki landasan untuk menentukan pilihan. Karakter virus Corona sangat berbeda dengan jenis penyakit epidemik lainnya seperti kolera, pes, influenza, flu burung, dan lain-lain. Covid-19 ini sangat menyiksa manusia. Jika dia sudah menjangkiti orang, bukan hanya pasien yang terinfeksi Corona yang diisolasi oleh pemerintah, tetapi seluruh warga masyarakat akan turut diisolasi, baik warga yang sakit maupun warga yang sehat. Tempat karantina di rumah sakit bagi yang sudah terinfeksi, sementara yang sehat, akan dikarantina di rumah masing-masing secara mandiri. Isolasi mandiri dilakukan untuk mencegah penyebaran virus Corona meluas ke masyarakat.

\section{Gambaran Kepatuhan Masyarakat dalam Upaya Pencegahan Covid-19}

Hasil analisis responden dengan masyarakat yang patuh terhadap anjuran pemerintah dalam pencegahan Covid-19 sebanyak 80 orang (70,2\%) yang tidak patuh terhadap anjuran pemerintah dalam pencegahan Covid-19 yaitu 34 orang (29,8\%). Tingkat kepatuhan masyarakat terhadap protokol kesehatan di masa pandemi Covid-19 dalam rangka pencegahan penyebaran Covid-19. ${ }^{1,2}$ Selain itu juga ingin melihat pengaruh faktor karakteristik sosial demografi masyarakat terhadap tingkat kepatuhan masyarakat dalam penerapan protokol kesehatan. Penelitian ini diharapakan dapat memberikan bahan masukan bagi pemangku kebijakan dalam menerapkan aturan pengendalian penyebaran Covid-19 dan memberikan pengawasan terhadap penerapan protokol kesehatan pada masyarakat. Menurut analisis peneliti bahwa persepsi keefektifan tindakan isolasi/arantina mandiri mempunyai pengaruh yang signifikan terhadap tingkat kepatuhan masyarakat dalam penerapan protokol kesehatan dengan arah hubungan yang positif. Tingkat kepatuhan protokol kesehatan pada masyarakat yang memiliki persepsi tindakan isolasi/karantina mandiri yang dilakukannya efektif dapat memperlambat proses penyebaran Covid-19. Kepatuhan masyarakat yang menganggap tidak efektif. Dengan kata lain, masyarakat yang memiliki persepsi bahwa tindakan isolasi/karantina mandiri yang dilakukannya efektif dapat memperlambat penyebaran Covid-19memiliki kecenderungan selalu taat dan patuh pada penerapan protokol kesehatan. ${ }^{4}$

\section{Hubungan Pengetahuan Wabah Covid-19 terhadap Kepatuhan Pencegahan Covid-19}

Hasil uji statistic Chi-Square dengan nilai Pearson chi-quare dengan nilai value 39.387 menggunakan SPSS 20 dengan tingkat kemaknaan 95\%, menunjukkan bahwa nilai probabilitas $0,000(\mathrm{p}<0,05)$, artinya Ho di tolak dan Ha diterima. Maka dapat disimpulkan bahwa ada yang signifikan dari hasil analisis mengenai hubungan antara pengetahuan tentang wabah Covid-19 terhadap kepatuhan dalam upaya pencegahan Covid-19 di Desa Dramaga Bogor. Selain itu, hasil analisa juga didapatkan data nilai Ordo Ratio sebesar 19.119 artinya yang memiliki pengetahuan tentang wabah kurang baik tentang Covid-19 dengan beresiko 22 kali kepatuhan masyarakat dalam upaya pencegahan Covid-19 yang kurang patuh dibandingkan dengan yang memiliki pengetahuan yang baik. Pengetahuan masyarakat tentang Covid-19 merupakan aspek yang sangat penting dalam masa pandemic seperti sekarang ini, yang meliputi penyebab Covid19 dan karakteristik virusnya, tanda dan gejala, istilah yang terkait dengan Covid-19 , pemeriksaan yang diperlukan dan proses transmisi serta upaya pencegahan penyakit tersebut. Pengetahuan masyarakat desa Dramaga yang tinggi tentang Covid-19 ini berpengaruh terhadap kejadian dan pencegahan penyakit Covid-19 .Pengetahuan yang baik dapat didukung oleh penerimaan terhadap informasi yang beredar di sebagian besar masyarakat tentang Covid-19 .

Hasil penelitian ini sejalan dengan Purnamasari, bahwa pengetahuan masyarakat tentang Covid-19 merupakan aspek yang sangat penting dalam masa pandemi seperti sekarang 
ini,yang meliputi penyebab Covid-19 dan karakteristik virusnya, tanda dan gejala, istilah yang terkait dengan Covid-19, pemeriksaan yang diperlukan dan proses transmisi serta upaya pencegahan penyakit terhadap upaya pencegahan Covid-19 di Indonesia dengan social distancing. ${ }^{13}$ Pengetahuan masyarakat khususnya dalam mencegah kemampuan transmisi penyebaran virus SARS-CoV-2 sangat berguna dalam menekan penularan virus tersebut. Dengan memiliki pengetahuan yang baik terhadap suatu hal, seseorang akan memiliki kemampuan untuk menentukan dan mengambil keputusan saat menghadapinya ${ }^{14}$.

Hasil penelitian ini sejalan dengan penelitian klinis yang dilakukan oleh Yanti et al., dimana dari 1.102 responden di Indonesia, mayoritas responden memiliki tingkat pengetahuan yang baik terkait social distancing dalam rangka pencegahan penularan COVID-19 dengan prevalensi mencapai 99\% ${ }^{10}$ Hasil penelitian ini sejalan dengan penelitian yang dilakukan oleh Yanti et al., dimana dari 1.102 responden di Indonesia, mayoritas responden memiliki sikap yang positif (53\%) dan perilaku yang baik (93\%) terkait penerapan social distancing. ${ }^{10}$

Perilaku masyarakat khususnya masyarakat Desa Sumerta Kelod sangatlah penting guna membantu masyarakat itu sendiri dalam mengenali serta mengatasi permasalahan COVID-19 yang menjadi pandemi di masa kini. Perilaku tersebut haruslah didasarkan atas kesadaran masyakat, dikarenakan banyak masyarakat yang sebenarnya telah mengetahui berbagai pengetahuan terkait protokol kesehatan ataupun pandemi COVID-19 namun tidak dapat melaksanakannya secara baik di dalam kehidupannya sehari-hari. ${ }^{15}$

Menurut asumsi dan analisis peneliti bahwa Seseorang yang telah mengetahui tentang suatu informasi tertentu, maka dia akan mampu menentukan dan mengambil keputusan bagaimana menghadapinya. Dengan kata lain, saat seseorang mempunyai informasi tentang Covid-19 , maka ia akan mampu untuk menentukan bagaimana dirinya harus berperilaku terhadap Covid-19 tersebut. Dengan demikian pengetahuan masyarakat yang masih perlu diluruskan dan perilaku masyarakat yang masih negatif dapat diupayakan dengan kegiatan pembelajaran melalui edukasi oleh pihak-pihak yang berwenang. Aturan karantina yang di anjurkan pemerintah memiliki dilemma dalam Kepatuhan masyarakat, dimana semua tindakan kesehatan masyarakat untuk menghentikan penyebaran penyakit dapat diseimbangkan dengan strategi adaptif untuk mendorong ketahanan masyarakat dan koneksi sosial, melindungi pendapatan dan mengamankan pasokan makanan.

\section{Kesimpulan}

Kesimpulan dalam penelitian ini bahwa pengetahuan tentang Wabah Covid-19 dan aturan karantina tergolong baik, sedangkan warga tergolong patuh terhadap anjuran pemerintah dalam pencegahan Covid-19. Selain itu terdapat hubungan antara pengetahuan tentang wabah Covid-19 dan aturan karantina terhadap kepatuhan dalam upaya pencegahan Covid-19 di Desa Dramaga Bogor. Sebaiknya Perawat yang bertugas hendaknya melakukan upaya-upaya meningkatkan pengetahuan masyarakat tentang Covid-19, membuat leaflet atau selemabaran tentang Covid-19.

\section{Konflik kepentingan}

Peneliti menyetakan bahwa pada penelitian ini tidak ada konflik kepentingan baik secara individu maupun organisasi. 


\section{Ucapan Terimakasih}

Peneliti mengucapkan terimakasih kepada semua pihak yang terlibat pada penelitian ini, terutama kepada responden penelitian.

\section{Pendanaan}

Sumber pendanaan diperoleh dari penulis.

\section{References}

1. NoV, Mona N. Konsep Isolasi Dalam Jaringan Sosial Untuk Meminimalisasi Efek Contagious (Kasus Penyebaran Virus Corona Di Indonesia). J Sos Hum Terap. 2020; 2(2):117-125. doi:10.7454/jsht.v2i2.86

2. Shereen MA, Khan S, Kazmi A, Bashir N, Siddique R. COVID-19 infection: Origin, transmission, and characteristics of human coronaviruses. J Adv Res. 2020;24:91-98. doi:10.1016/j.jare.2020.03.005

3. Bausch DG. Precision physical distancing for COVID-19: An important tool in unlocking the lockdown. Am J Trop Med Hyg. 2020;103(1):22-24. doi:10.4269/ajtmh.20-0359

4. Devi Pramita Sari, Nabila Sholihah 'Atiqoh. Hubungan Antara Pengetahuan Masyarakat Dengan Kepatuhan Penggunaan Masker Sebagai Upaya Pencegahan Penyakit Covid-19 Di Ngronggah. Infokes J Ilm Rekam Medis dan Inform Kesehat. 2020;10(1): 52-55. doi:10.47701/infokes.v10i1.850

5. Istyanto F, Maghfiroh A. Jurnal Ilmiah Permas: Jurnal Ilmiah STIKES Kendal. Peran Mikronutrisi Sebagai Upaya Pencegah Covif-19. 2021;11:1-10.

6. Aquarini A. Pengaruh Kebijakan Politik Terhadap Kepatuhan Physical Distancing Mencegah Penyebaran Covid-19. Anterior J. 2020;19(2):66-73. doi:10.33084/anterior.v19i2.

7. Notoatmodjo, Soekidjo. Metodologi Penelitian Kesehatan. Jakarta: Rineka Cipta; 2012.

8. Sugiyono. Metode Penelitian Kuantitatif, Kualitatif dan R\&D. Bandung: ALFABETA; 2012.

9. Arikunto, Suharsimi. Prosedur Penelitian Suatu Pendekatan Praktik. Jakarta: Rineka Cipta; 2013

10. Yanti B, Wahyudi E, Wahiduddin W, et al. Community Knowledge, Attitudes, and Behavior Towards Social Distancing Policy As Prevention Transmission of Covid-19 in Indonesia. J Adm Kesehat Indones. 2020;8(2):4. doi:10.20473/jaki.v8i2.2020.4-14

11. Nurul Aula SK. Peran Tokoh Agama Dalam Memutus Rantai Pandemi Covid-19 Di Media Online Indonesia. Living Islam J Islam Discourses. 2020;3(1):125. doi:10.14421/ lijid.v3i1.2224

12. Yuliana Y. Corona virus diseases (Covid-19): Sebuah tinjauan literatur. Wellness Heal Mag. 2020;2(1):187-192. doi:10.30604/well.952120

13. Purnamasari. Tingkat Pengetahuan Dan Perilaku Masyarakat Kabupaten Wonosobo Tentang Covid-19. Jurnal Ilmiah Kesehatan, 10(1), 2020. 33-42.

14. Wang, Handbook of 2019-nCoV pneumonia control and prevention, (China: Hubei Science and Technology Press); 2020.

15. Sulistyaningtyas. Informasi Wabah Virus Covid-19: Kuasa Pengetahuan dan Kelas Sosial, https://sinta.ristekbrin.go.id/covid/penelitian/detail/80, publish : 2020. 